\title{
The Hymnbook of Valentin Triller (Wrocław 1555): Musical Past and Regionalism in Early Modern Silesia. By Antonio Chemotti.
}

Warsaw: Instytut Sztuki Polskiej Akademii Nauk, 2020. 292 pp.

The Polyphonic Hymns of Valentin Triller's Ein Schlesich singebüchlein (Wrocław 1555). By Antonio Chemotti.

Warsaw: Instytut Sztuki Polskiej Akademii Nauk, 2019. 157 pp.

\section{Allen Scott}

315 Greenwood School of Music, Oklahoma State University, Stillwater, OK 74078, USA

allen.scott@okstate.edu

In 1555, the Silesian pastor and editor Valentin Triller partnered with the Wrocław printer Crispin Scharffenberg to produce a hymnbook titled Ein Schlesich singebüchlein (A Silesian Songbook). This work, however, was far more than an ordinary collection of hymns for congregational or private devotional use. According to Antonio Chemotti, "The dialogue between the hymnbook's paratexts and content offers a unique perspective on the musical culture of mid-sixteenth-century Silesia. In this regard I will suggest that appropriate geographical contextualisation is essential for the comprehension of Ein Schlesich singebüchlein, whose embeddedness in a regional context is suggested by its very title." Chemotti's primary goal in this monograph is to closely examine "the relation between the hymnbook and the cultural climate of Silesia" and attempt "an interpretation of Ein Schlesich singebüchlein as an expression of a »Silesian culture «" In this monograph, he succeeds in a masterful way.

In chapter one Chemotti aims "to situate Ein Schlesich singebüchlein within a specific production system, and to gather all of the available information regarding the life and work of its editor." In 1552, printer Crispin Scharffenberg moved to Wrocław and purchased the printing firm of Andreas Winkler. Over the course of his career in Wrocław, he printed a total of 13 volumes with musical notation. Ein Schlesich singebüchlein was Scharffenberg's first hymnbook and the first hymnbook to appear in Silesia since Adam Dyon's Gesang Buchlien in 1525. The hymnbook first appeared in print in 1555 with the title Ein Schlesich singebüchlein (A Silesian Songbook). It was reissued in 1559 with a new title page: Ein Christlich Singebuch (A Christian Songbook). The contents of the hymnbook remained the same. 
Most likely the unsold copies from the 1555 print run were repackaged with a new title page. What little we know of the editor, Valentin Triller, can be gleaned from the publication's paratexts: he was born in Silesia, was the Lutheran pastor in the village of Panthenau in the duchy of Brieg (Polish Brzeg), was married, and had children. According to Chemotti, Triller collectively referred to the hymns in Ein Schlesich singebüchlein as "my songs" (meine gesenge), so there is no reason to think that he was not also the author of many of the texts.

In chapter two, Chemotti discusses the paratexts that introduce the hymnbook, focusing on the title page, dedicatory letter, and preface. He begins by discussing the geographical implications of the title page, noting that Triller expressly called the collection a "Silesian" hymnbook. The reference to Silesia goes beyond its dedication to Georg II, Duke of Liegnitz and Brieg, to encompass the whole of Silesia as a region. This regional identification is expanded in the "Preface to the Christian Reader," in which Triller refers to "our Silesia." According to Chemotti, "The ideal reader Triller imagined while writing the preface was another fellow Silesian. ... Thus, the 'Christian reader' addressed in the forward is not characterised just by a religious identity, but implicitly also by a regional one." In the dedication letter Triller expands the geographical emphasis of the hymnbook to include issues of religious identity that appeared in the region. After addressing the dedicatee and discussing the theological idea of music as a gift of God to be used as a means of making an appropriate "sacrifice of praise," Triller turns to ideas of religious identity in Silesia. Chemotti explains that heterodox theological views had been spreading through the region among groups of spiritualists and Anabaptists since the 1520s. The most prominent spiritualist group was comprised of the followers of Kaspar Schwenckfeld, who, among other heresies, did not acknowledge the real presence of Christ in the Eucharist. Triller argues that the presence of such groups tainted not only the reputation of the Lutheran church, but also undermined the spiritual and temporal authority of Georg II, who was engaged in ridding the duchy of the heresy. His dedication letter also includes a short confession of faith, drawn from the Augsburg Confession. According to Chemotti, "Taking all its parts into consideration, the dedication letter adds an important political and religious dimension to the hymnbook. It presents the collection of hymns as a manifesto of faith, with the unconcealed intent of declaring the Lutheranism of the ecclesiastical community living in the lands of Duke Georg II." The hymnbook, therefore, acquired a confessional meaning. In addition to viewing the hymnbook as a declaration of Lutheran orthodoxy, Chemotti suggests that its design made Triller's hymnbook operate in a way similar to Lutheran church orders.

"Ein Schlesich singebüchlein is not a randomly assembled collection of hymns. Quite the contrary, its contents, structure, and paratexts reveal 
a coherent plan for framing the soundscape of vernacular devotions and liturgies, constituting a musical counterpart to the regulations we find in sixteenth-century church orders."

In chapter two, Chemotti also analyzes "what sorts of values could be attached to musical repertories perceived as old, irrespective of the actual nature of these repertories in terms of age, genre, or language." Some Lutheran hymnbooks promoted "old songs" as examples of pious Christians who knew the truth in the dark days of false doctrine. But these opinions centered on the texts, not the music of the old songs. Triller focused on the melodies of the old songs (the "old familiar melodies"). "It is clear that Triller's interest in the 'old melodies' was music- rather than text-oriented." Another of Triller's reasons for publishing a hymnbook is that many songbooks circulating in Silesia had unfamiliar foreign melodies or were poorly made. The word "foreign" can also be viewed geographically (meaning outside Silesia). All in all, Triller seems to consider the hymnbook's repertory to be a waning tradition, and the publication is "presented as some sort of commemorative volume, a Gedenkschrifft to save a musical heritage.... The past to which Triller refers is not the biblical past, but the experienced and personally remembered past. "Triller's Preface to the Christian Reader remains a unique testimony of an early modern awareness of the past in music, an awareness that it is related to a collective identity based on a sense of belonging to a region."

At the end of chapter two, Chemotti asks who may have been the intended user of Ein Schlesich singebüchlein. "Besides the aspects discussed above, the paratexts include some thought-provoking remarks concerning the ideal user Triller envisioned for Ein Schlesich singebüchlein." According to Triller, the hymnbook was published "for the benefit of the Christians who live about us, especially in the villages, who do not always know how to sing different, difficult notes and poems." However, some characteristics of the hymnbook suggest that some of the pieces were intended for trained singers. Chemotti states,

"I think that Ein Schlesich singebüchlein was primarily conceived for the person responsible for leading the singing in a church ... This person could have involved other performers ... depending on the genre of the hymn and the available musical forces. ... Triller's hymnbook, like many others, certainly could have been used in a domestic environment, but several features suggest that its editor was first and foremost thinking of public worship."

In chapter three, Chemotti discusses the order that underlies Ein Schlesich singebüchlein, examining rubrics, the order of the hymns, their texts, and their hymn tunes. Hymns 1 and 145 frame the collection with suitable hymns for the opening and closing of a Christian celebration. Hymns 2 through 144 are organized 
according to type and function. For example, hymns 2-56 are a set of hymns de tempore, numbers 57-66 are hymns on the Christian church and sanctorale, numbers 67-76 are hymns for the entire church year, numbers $77-83$ are metrical psalms, numbers $86-100$ are hymns for times of distress and for thanksgiving, and so on. According to Chemotti, Triller "published 145 vernacular hymns and organised them in a coherent collection, easing their retrieval and instructing the reader in their use. In doing so, he largely relied on pre-existing customs, some of which were rooted in late medieval practices, while others had more modern foundations." Through his hymnbook, "Triller aimed at reforming the soundscape of vernacular Lutheran liturgy and devotion in Silesia."

Chapter four, the largest and most extensive chapter, is chiefly concerned with the musical repertory itself. Chemotti first analyzes musical aspects such as type of notation and number of parts. He observes that Ein Schlesich singebüchlein "uses two notational systems: German gothic notation, sometimes including mensural elements, and white mensural notation. Eighty-one hymns are monodic, while fifty-one are polyphonic. Four further hymns consist of just one part, but it is likely that Triller envisaged them for polyphonic performance. Many of the hymns that are notated for more than one part could also be performed monodically. Nine hymns have no musical notation, but they carry title rubrics that refer to one or more appropriate hymn tunes." Chemotti next examines the genre definitions that appear on the title page and in the title rubrics accompanying each hymn. He finds that the majority of the hymn tunes were sung with a Latin sacred text. In the title rubrics, Triller identifies the chants by genre: antiphon, benedicamus, hymn, introit, prosa, etc. The majority of hymn tunes Triller used were office hymns, sequences, and antiphons. Chemotti also observes Triller's labelling of many songs as old or old and familiar. These labels confirm that Triller "regarded the repertory's age as a fundamental aspect of the hymnbook worth underscoring." It is interesting to note that none of the chant tunes are labeled as "old."

Chemotti then discusses the circulation of the hymn tunes, comparing them to the printed Kirchenlied tradition and the content of the hymnbooks issued before Triller's. Is the repertory in Ein Schlesich singebüchlein really different from other hymnbooks? Chemotti compared Triller's repertory to the standard modern source Das deutsche Kirchenlied and found that of 117 hymn tunes from Ein Schlesich singebüchlein, more than half did not appear in any hymnbook predating Triller's. "This aspect is of supreme importance: not only was Ein Schlesich singebüchlein not a reprint of a pre-existing source, but even for the individual hymn tunes Triller resorted largely to a hitherto unexploited repertory."

After analyzing the monophonic hymns, Chemotti examines the circulation of the polyphonic hymn settings. In Ein Schlesich singebüchlein there are fifty-one polyphonic 
hymns. Twenty-three of them are found in sources that predate Triller's hymnbook. The remaining twenty-eight hymns are unica. Chemotti concludes that he is "unable to detail the chronological and geographical distribution of the unica, but it seems safe to assume that they were 'at home' in Silesia and in the neighboring regions." He notes that there are "general stylistic affinities" between the unica and the musical style cultivated in central Europe, especially in polyphonic settings of the same cantus firmus.

Of the twenty-three polyphonic hymns with concordances older than Ein Schlesich singebüchlein, Chemotti finds that they had been circulating for decades, with some dating back to the first half of the fifteenth century. After discussing the Bohemian connection of the concordances, Chemotti examines two of Triller's polyphonic hymns with Bohemian connections: contrafacta of Vani sancte spiritus - Da gaudiorum and Martir felix insignita in depth. Chemotti next analyzes the connections between Triller's contrafacta of German secular polyphonic songs and some of the German sacred songs using Ach mein Got sprich mir freuntlich zu and its model Ein Maidlein sagt mir freundlich $z u$ as a case study.

In the concluding chapter, Chemotti asks what impact Ein Schlesich singebüchlein really had. In order to answer the question, he conducts a detailed study of the surviving copies and examines the circulation of its hymns in other printed and handwritten collections. He notes that although Triller's hymnbook was not a great commercial success (we don't know how many copies were produced and it was never reprinted), it did have an impact on hymnody in Silesia and the region in the sixteenth and seventeenth centuries. For example, two important collections document an early modern, non-Silesian reception of Triller's hymnbook: Leisentrit's Geistliche Lieder und Psalmen (1567) and other Catholic hymnbooks, and various seventeenth-century Lutheran hymn collections, including Praetorius's Musae Sioniae. Although Ein Schlesich singebüchlein might seem to have been of secondary importance, published by an obscure pastor in a region on the periphery of great musical developments in the sixteenth century, it does have its value in early modern sacred music history. As Chemotti points out, "it is a source offering great potential for scholars interested in the history of its peculiar hymn tunes as well as vernacular hymnody in general."

Antonio Chemotti's The Hymnbook of Valentin Triller is a detailed, in-depth historiographic examination of a significant source in the history of Reformation hymnody in Silesia. The author's exceptionally close reading of the hymnbook's texts and paratexts reveals a wealth of information about the transmission and use of monophonic and polyphonic hymns in a particular region, time, and culture. More than just a study of a particular hymnbook, Chemotti's work is a model example of historical and historiographical writing. The Hymnbook of Valentin Triller deserves, and rewards, as close a reading as Chemotti gave to his subject. 
In 2019, Chemotti edited and published The Polyphonic Hymns of Valentin Triller's Ein Schlesich singebüchlein, which serves as both an independent examination of a single repertory and as a companion volume to The Hymnbook of Valentin Triller. Its subject matter is the fifty-one explicitly polyphonic hymns found in Ein Schlesich singebüchlein. Eight of the hymns are set for two voices and forty-three are set for three voices.

Chemotti's edition contains three major sections. Section one, the introduction, is an extensive description of the hymns and a discussion of the editorial decisions made. After a brief introduction to the hymnbook, Chemotti describes the polyphonic hymns and their layout. Because Triller's hymnbook is in choirbook format, the individual parts are printed consecutively. Chemotti argues that, because of this layout, each part would have to have been transcribed to another medium (a performance copy) or memorized for performance. Chemotti also notes that there are two different voice dispositions used. Sometimes the first voice presented is the discantus part and sometimes the first voice presented is the tenor part. Apparently Triller placed the voice containing the pre-existent hymn melody first so as to aid in identification of each tune.

Chemotti next analyzes the "implicitly" polyphonic hymns found in the hymnbook. Four of the hymns were printed as monophonic melodies, yet they could have been performed polyphonically. The hymn melodies are labeled "Tenor" and all four are contrafacta of popular polyphonic Lieder circulating in Silesia. Therefore, it would have been relatively easy for them to be performed using all voices of the model. (The polyphonic Lieder are given in Appendix B). Chemotti then notes that "one of the extant copies of Valentin Triller's hymnbook, PL-Wu SDM 93, carries various handwritten annotations and corrections, mostly made by one scribe at the turn of the sixteenth century." Nine of the hymns "were reworked in a very substantial way through the addition of substitutive parts and/or the rewriting of the printed ones." (These nine hymns are given in Appendix A.)

In the next subsection, Chemotti provides an overview of the two types of notation found in the hymnbook (white mensural and German gothic with mensural elements). A majority of the hymns are in binary meter with a "cut-C" mensuration sign. Those that are in triple meter begin with a "cut-C-3" sign. Five of the hymns change from duple to triple meter at some point; in each case a plain " 3 " is used to indicate the triple meter section. In the final subsection Chemotti describes the critical edition, methods of text underlay, and placement of editorial accidentals.

Section two contains a modern edition of the polyphonic hymns in order of appearance. Section three consists of Appendixes A and B and the Critical Apparatus. The Critical Apparatus contains basic information about the hymns, including rubrics, folio number, the modern edition of the text in Wackernagel's 
Das deutsche Kirchenlied von der ältesten Zeit bis zu Anfang des XVII. Jahrhunderts, the text incipit of the hymn tune used as the model for the contrafactum, references to the hymn tune or Triller's contrafactum in Das Deutsche Kirchenlied, information on cleffing and mensural signs, notes to the edition, and notes on the text underlay.

Many, if not most, studies of Reformation church song only concern monophonic chorales and chorale motets in High Renaissance style. In The Polyphonic Hymns of Valentin Triller's Ein Schlesich singebüchlein Antonio Chemotti examines another type of Reformation polyphonic song meant for communal worship by common people in small parishes with few musical resources. These hymns are not just polyphonic settings of Reformation standards handed down from Wittenberg and associated composers. In many cases, they are settings of popular hymns that apparently had been circulating in Silesia for generations. In his work, Chemotti has provided not just an in-depth look at a selected repertory in a particular hymnbook, but also has given us a glimpse into the sacred musical world of ordinary worship in mid-sixteenth-century Silesia. 